\title{
AKSESIBILITAS MEDIA SOSIAL DALAM INTERAKSI ANTAR ANGGOTA KELUARGA URBAN
}

\author{
Ditha Prasanti dan Putri Limilia \\ Fakultas Ilmu Komunikasi, Universitas Padjadjaran \\ Jl. Raya Jatinangor-Sumedang KM. 21 Bandung \\ Email: dithaprasanti@gmail.com
}

\begin{abstract}
This article is the result of further research on the study of the resilience of urban families in the digital era, which focuses on the accessibility of social media in the interaction between members of the urban family. Urban family is an interesting study to be discussed because of the current concept that demands the development of the digital era. Urban families, as family members living in urban areas, have a large level of social media accessibility, so interaction between family members is also possible through social media. This is interesting to discuss because the author wants to reveal the accessibility of social media in the interaction between members of the urban family. In this study, the author uses a qualitative approach, with data collection techniques, in the form of interviews; observation; and documentation study. Accessibility of social media in the interaction between members of the urban family produces varied findings, including the existence of family conflicts caused by the accessibility of social media; enabling the dissemination of information on social media as a result of the interaction of members of the urban family; the emergence of social media group networks as a forum for interaction between members of the urban family. Based on these findings, the authors see the existence of positive and negative points that can be generated as a result of the accessibility of social media used by members of urban families.
\end{abstract}

Keywords: Accessibility, Social Media, Interaction, Urban Family.

Abstrak: Artikel ini merupakan hasil penelitian lanjutan tentang kajian ketahanan keluarga urban di era digital, yang memfokuskan pada aksesibilitas media sosial dalam interaksi antar anggota keluarga urban tersebut. Keluarga urban menjadi kajian menarik untuk dibahas karena konsep kekinian yang menuntut perkembangan era digital. Keluarga urban, sebagai anggota keluarga yang tinggal di perkotaan, memiliki tingkat aksesibilitas media sosial yang besar, sehingga interaksi antar anggota keluarga pun sangat memungkinkan dilakukan melaui media sosial tersebut. Hal ini menarik untuk dibahas karena penulis ingin mengungkapkan aksesibilitas media sosial dalam interaksi antar anggota keluarga urban. Dalam kajian ini, penulis menggunakan pendekatan kualitatif, dengan teknik pengumpulan data, berupa wawancara; observasi; dan studi dokumentasi. Aksesibilitas media sosial dalam interaksi antar anggota keluarga urban ini menghasilkan temuan yang bervariatif, di antaranya adalah adanya konflik keluarga yang disebabkan oleh aksesibilitas media sosial tersebut; memungkinkan terjadinya penyebaran informasi hoaks dalam media sosial sebagai hasil dari interaksi anggota keluarga urban; munculnya jaringan group media sosial sebagai wadah interaksi antar anggota keluarga urban tersebut. Berdasarkan temuan tersebut, penulis melihat adanya point positif dan negatif yang dapat ditimbulkan sebagai hasil dari aksesibilitas media sosial yang digunakan oleh anggota keluarga urban.

Kata Kunci: Aksesibilitas, Media Sosial, Interaksi, Keluarga Urban.

\section{PENDAHULUAN}

Lee dan Chee (2007) melakukan penelitian tentang media sosial dalam konteks komunikasi keluarga. Mereka melakukan survei terhadap 222 anak-anak di Korea kelas 
empat, lima, dan enam untuk memeriksa (a) apakah penggunaan internet anak-anak mempengaruhi penurunan waktu keluarga dan komunikasi keluarga dan (b) bagaimana teknik mediasi orang tua terkait dengan kegiatan online anak-anak. Menurut temuan, total waktu menggunakan Internet terkait dengan penurunan yang dirasakan dalam waktu keluarga tetapi tidak terkait dengan komunikasi keluarga. Pengaruh Internet pada waktu keluarga dan komunikasi keluarga berbeda dengan jenis kegiatan online anak-anak. Analisis hubungan antara teknik mediasi orangtua dan aktivitas online anak-anak menunjukkan bahwa rekomendasi orang tua tentang situs Web yang bermanfaat dan penggunaan bersama secara positif terkait dengan frekuensi kegiatan online pendidikan anak-anak. Namun, pembatasan orang tua pada waktu dan situs Web tidak mengubah penggunaan Internet aktual anak-anak (Lee, S. J., \& Chae, 2007).

Penggunaan internet dalam kajian di atas menunjukkan adanya nilai urgensitas bagi penulis dalam melakukan penelitian ini. Urgensitas tersebut ditunjukkan dengan adanya trend media sosial yang digunakan dalam interaksi antar anggota keluarga, khususnya dalam hal ini cakupannya adalah keluarga urban. Penulis melihat hal ini sebagai urgensitas, karena era digital ini telah membuat adanya perubahan proses komunikasi yang terjadi, bahkan dalam konteks interaksi antar anggota keluarga.

Oleh karena itu, penulis ingin mengetahui aksesibilitas media sosial yang terjadi dalam interaksi antar anggota keluarga urban. Hal ini perlu diungkapkan agar kita dapat memperoleh gambaran tentang aksesibilitas media sosial yang selama ini digunakan dalam interaksi antar anggota keluarga urban. Dalam hal lain, penulis melihat adanya nilai kebaruan penelitian, karena para peneliti terus melakukan pembaharuan data hasil penelitian dalam hal platform media sosial bagi komunikasi keluarga.

Penelitian lainnya dilakukan oleh Wilding (2006) yang mengangkat analisis tentang penggunaan Teknologi Informasi dan Komunikasi (TIK) berfokus pada faktor-faktor seperti gender, kelas dan infrastruktur komunikasi. Artikel tersebut juga menjelaskan bagaimana berkomunikasi jarak jauh. Wilding (2006) berpendapat bahwa analisis tersebut gagal menangkap kompleksitas penuh penggunaan TIK. Penelitian tersebut merupakan studi kualitatif kepada konteks keluarga transnasional, yang dilakukan di Australia, Irlandia, Italia, Belanda, Iran, Singapura dan Selandia Baru, untuk memeriksa bagaimana dan apakah kerabat menjaga kontak lintas waktu dan ruang. Penelitian menunjukkan bahwa Teknologi Informasi dan Komunikasi (TIK) lebih tersedia untuk beberapa orang daripada untuk orang lain. Namun, ada hal yang lebih penting dalam keputusan yang diambil orang tentang penggunaan teknologi komunikasi tertentu yaitu konteks sosial dan budaya kehidupan keluarga, yang membuat beberapa TIK lebih diinginkan daripada yang lain pada titik waktu tertentu (Wilding, 2006).

Kebaruan penelitian yang terdapat dalam penelitian penulis adalah memfokuskan aksesibilitas media sosial yang terjadi pada bagian interaksi antar anggota keluarga urban. Berbeda halnya dengan kedua penelitia terdahulu di atas yang melihat platform media sosial dalam konteks keluarga, tetapi cakupannya lebih luas. Sedangkan penulis menitikberatkan pada point yang lebih spesifik tentang aksesibilitas media sosial dalam interaksi antar anggota keluarga urban.

Artikel ini merupakan hasil penelitian lanjutan tentang kajian ketahanan keluarga urban di era digital, yang memfokuskan pada aksesibilitas media sosial dalam interaksi antar anggota keluarga urban tersebut. Keluarga urban menjadi kajian menarik untuk dibahas karena konsep kekinian yang menuntut perkembangan era digital. 
Keluarga urban, sebagai anggota keluarga yang tinggal di perkotaan, memiliki tingkat aksesibilitas media sosial yang besar, sehingga interaksi antar anggota keluarga pun sangat memungkinkan dilakukan melaui media sosial tersebut. Hal ini menarik untuk dibahas karena penulis ingin mengungkapkan aksesibilitas media sosial dalam interaksi antar anggota keluarga urban.

\section{METODE}

Dalam penelitian ini, penulis menggunakan pendekatan kualitatif untuk memaparkan fenomena penelitian tersebut. Hal ini sejalan dengan tujuan penulis untuk menggambarkan fenomena penelitian yang terjadi di lapangan. Dalam hal ini, penulis mengangkat topik tentang aksesibilitas media sosial dalam interaksi antar anggota keluarga urban.

Bungin (2007) mengatakan bahwa deskripsi merupakan penelitian eksplorasi dan memainkan peran penting dalam menciptakan pemahaman orang tentang bebagai variabel sosial. Studi ini disifatkan sebagai ekplorasi, jadi tidak bertujuan menguji hipotesis, atau membuat generalisasi (Bungin, 2007).

Penulis menggunakan teknik pengumpulan data berupa observasi, wawancara, dan studi dokumentasi. Pertama, langkah yang dilakukan penulis adalah melakukan observasi. Observasi atau pengamatan penting dilakukan untuk mengetahui gambaran awal dari fenomena yang terjadi di lapangan, yaitu dalam hal mencari informan penelitian yang memenuhi kriteria penelitian juga. Kedua, wawancara dilakukan kepada informan penelitian yang terpilih dan sesuai dengan kriteria penelitian penulis. Ketiga, penulis melakukan studi dokumentasi, dalam hal untuk mencari referensi yang relevan dengan topik penelitian penulis, yaitu jurnal-jurnal ilmiah internasional yang membahas media sosial dalam konteks komunikasi keluarga. Selain itu, buku dan sumber lainnya yang menunjang kebutuhan data penelitian.

\section{Informan Penelitian}

Dalam penelitian ini, penulis menggunakan teknik purposive sampling, yaitu memilih informan yang sesuai dengan kriteria utama penelitian ini. Oleh karena itu, penulis juga menentukan kriteria informan terlebih dahulu. Kriteria tersebut yaitu informan merupakan bagian dari keluarga urban, yaitu anggota keluarga yang tinggal di perkotaan. Dalam hal ini, penulis membatasi lokasinya, yaitu kota Jakarta, Tangerang, Bekasi, dan Bandung. Kriteria selanjutnya, informan aktif minimal 5 tahun terakhir menggunakan media sosial dalam interaksi dengan anggota keluarganya. Adapun informan yang terpilih yaitu:

1. IDR, 38 tahun, Bandung

2. DF, 32 tahun, Jakarta

3. ADN, 36 tahun, Tangerang

4. KW, 35 tahun, Bekasi

\section{HASIL DAN PEMBAHASAN}

Aksesibilitas media menjadi hal yang perlu dipertimbangkan bagi sebagian kalangan saat ini, khususnya dalam pencarian informasi melalui media tersebut. Kajian inipun berkembang seiring dengan munculnya penggunaan media sosial dalam interaksi manusia. Dalam penelitian ini, penulis ingin mengungkapkan aksesibilitas media sosial 
dalam interaksi antar anggota keluarga urban. Betapa pentingnya aksesibilitas media sosial, sehingga penulis pun menemukan salah satu penelitian yang dilakukan oleh Derwin, Suharto, dan Syamsuri (2016) tentang aksesibilitas media sosial dakwah bagi kalangan mahasiswa di Palu. Dalam artikel tersebut dijelaskan bahwa pengguna media sosial semakin bertambah. Kemudahan dalam mengoperasikan dan mengakses, biaya akses yang murah, hadirnya aplikasi-aplikasi yang menarik, serta inovasi yang dilakukan provider ikut ambil bagian dalam peningkatan jumlah pengguna media sosial ini, khususnya bagi kalangan mahasiswa. Aksesibilitas media sosial pun dijadikan sebagai sarana silaturahmi, media dakwah, mengakses informasi islam, dan sebagai lahan bisnis online (Derwin, Suharto, \& Syamsuri, 2016).

Berbeda dengan kalangan mahasiswa yang menggunakan media sosial sebagai akses untuk berdakwah, penulis menemukan hasil yang lain tentang interaksi anggota keluarga urban ini. Penelitian lainnya tentang aksesibilitas media internet di kalangan anak dan orang tua juga dilakukan oleh Odabasi (2005). Odabasi (2005) menjelaskan tentang penggunaan internet yang efektif oleh anak-anak sangat bergantung pada faktor-faktor di sekitarnya, sehingga pandangan dan sikap orang tua sangat penting bagi penggunaan Internet oleh anak-anak sekolah dasar. Selain itu, kesadaran orang tua tentang Internet membantu orang tua untuk merenungkan masalah terkait Internet. Artikel tersebut mencoba mengungkap pandangan orang tua anak-anak sekolah dasar di Internet. Kuesioner yang terdiri dari 17 item mengenai aspek keuangan, sosial, pendidikan, dan keamanan Internet digunakan untuk mengumpulkan data. Penelitian tersebut dilakukan kepada 94 orang tua; survei menunjukkan bahwa orang tua mengamati Internet sebagai media ekonomi, agak tidak menyadari masalah keselamatan, percaya bahwa Internet meningkatkan prestasi akademik, dan merupakan kebutuhan kehidupan kontemporer. Sorotan lain dari penelitian tersebut adalah bahwa orang tua tidak percaya bahwa penggunaan Internet berdampak negatif pada hubungan keluarga (Odabasi, 2005).

Penelitian kedua di atas dilakukan pada tahun 2005 dan memiliki fokus kajian yang berbeda dengan penulis. Meskipun pada akhir artikelnya tertulis bahwa orang tua tidak percaya tentang penggunaan internet yang berdampak negatif pada hubungan keluarga, tetapi hal tersebut bukan berarti berlaku dalam semua perspektif tentang interaksi keluarga.

Dalam penelitian penulis, aksesibilitas media sosial dalam interaksi antar anggota keluarga urban ini menghasilkan temuan yang bervariatif, meliputi adanya konflik keluarga yang disebabkan oleh aksesibilitas media sosial tersebut; memungkinkan terjadinya penyebaran informasi hoaks dalam media sosial sebagai hasil dari interaksi anggota keluarga urban; munculnya jaringan group media sosial sebagai wadah interaksi antar anggota keluarga urban tersebut.

Berdasarkan temuan tersebut, penulis melihat adanya point positif dan negatif yang dapat ditimbulkan sebagai hasil dari aksesibilitas media sosial yang digunakan oleh anggota keluarga urban.

\section{Temuan pertama adalah adanya konflik keluarga yang disebabkan aksesibilitas media sosial tersebut.}

Point ini disampaikan oleh ADN dalam kutipan wawancaranya sebagai berikut:

"Kalo gue liat kemudahan akses media sosial ini ya justru jadinya malah timbul masalah baru di kalangan keluarga, hehe.. ya kan conversationnya dilakukan di 
group keluarga gitu, kadang ada yang negur langsung tuh, kan gak enak jadinya ribut. Bisa jadi karena masalah sepele gitu, tapi kan tetap aja jadi memicu konflik antar anggota keluarga yang ada di group itu."

Dalam pernyataan tersebut, penulis melihat bahwa menurut ADN, aksesibilitas media sosial yang terjadi dalam interaksi antar anggota keluarga urban tersebut justru menimbulkan adanya konflik keluarga. Meskipun konflik tersebut disebabkan karena masalah kecil, tetapi konflik tetap terjadi. Bahka IDR pun menambahkan bahwa aksesibilitas media sosial yang digunakan oleh anggota keluarganya, menyebabkan ada beberapa anggota keluarga yang memilih keluar dari group. Tetapi beberapa minggu kemudian, setelah konflik mereda, anggota keluarga pun diundang lagi ke dalam group tersebut. Berikut ini kutipan wawancaranya.

"Keluargaku pake media sosial whatsapp group untuk berkomunikasi. Keluarga besar pula. Jadi interaksi antar anggota keluarganya ya terjadi di dalam group itu. Positifnya ya sarana silaturahmi ya, karena lokasi tempat tinggal kami tuh berjauhan, lintas pulau. Tapi negatifnya, jadi lebih sering terjadi konfliknya, hehe.. Sepupuku yang sering ditegur secara terang-terangan di dalam group, jadinya left group. Ini tuh sering banget, hehe. Tapi abis itu, nanti disinvite lagi sih akhirnya. Ya aku juga pernah ditegur gitu kata-katanya gak enak, dan itu di dalam group juga, terang-terangan. Intinya, akses media sosial yang dipake untuk interaksi antar anggota keluarga ini, ya seringkali emang menimbulkan konflik antar anggota keluarga."

Kutipan wawancara di atas menegaskan informan pertama yang bercerita tentang konflik antar anggota keluarga dalam media sosial whatsapp group keluarganya. Ternyata hal serupa pun disampaikan juga oleh IDR. Hal tersebut menjadi temuan pertama penulis mengenai aksesibilitas media sosial yang ada dalam interaksi antar anggota keluarga.

Temuan kedua, memungkinkan adanya penyebaran informasi hoaks dalam media sosial tersebut.

Dalam hal ini, penulis menemukan adanya kesamaan yang disampaikan oleh para informan bahwa aksesibilitas media sosial tersebut memungkinkan adanya penyebaran informasi hoaks antar anggota keluarga. Penyebaran informasi hoaks tersebut disampaikan oleh beberapa anggota yang begitu saja langsung memposting informasi apapun, tanpa mengecek kebenarannya terlebih dahulu.

Hal ini terlihat jelas dalam pernyataan yang disampaikan oleh DF tentang kemungkinan informasi hoaks yang tersebar dalam media sosial whatsapp group di lingkungan keluarganya. Berikut ini adalah penuturannya.

"Aku liat sih aksesibilitas medsos ini memungkinkan adanya penyebaran informasi hoaks gitu. Sebenernya ya bukan hanya di group keluarga ya, dimanapun mungkin terjadi. Tapi kan kalau di whatsapp group keluarga tuh ya kayak sharing informasi gitu, tapi kadang-kadang ada informasi yang hoaks, belum tentu kebenarannya." 
Pernyataan di atas menunjukkan adanya data bahwa aksesibilitas media sosial dalam interaksi antar anggota keluarga urban tersebut adalah memungkinkan terjadinya penyebaran informasi hoaks. IDR juga menambahkan bahwa informasi yang bersifat hoaks ini biasanya karena ketidaktahuan anggota keluarga, misalnya ada anggota keluarga yang sudah berusia lanjut, tetapi aktif dalam mengakses media sosial, lalu ketika mendapatkan informasi apapun, langsung disebarkan kembali dalam group keluarga. Informasi yang sering diperoleh dan disebarkan adalah informasi tentang agama dan kesehatan.

Penelitian tentang informasi hoaks juga pernah dilakukan oleh Pinheiro, Cappelli, \& Maciel (2014) yang menjabarkan tantangan bagaimana memberikan informasi yang dapat diaudit kepada warga mengenai jaringan media sosial. Tujuannya adalah untuk membahas masalah-masalah mengenai informasi yang dipublikasikan di jejaring media sosial, dan secara khusus menggambarkan memverifikasi kebenaran informasi. Hal ini didasarkan pada gagasan bahwa peningkatan kebutuhan informasi yang mendesak sehingga diperlukan cara bagi para pengguna untuk memperhitungkan, memvalidasi, memverifikasi, dan mengendalikan informasi. Sebuah studi eksplorasi menyarankan mekanisme yang dapat digunakan untuk mengimplementasikan karakteristik informasi tersebut. Kesimpulannya menyajikan komentar tentang tantangan dan studi masa depan mengenai informasi yang tersebar (Pinheiro, A., Cappelli, C., \& Maciel, 2014).

Penelitian di atas menguatkan hasil penelitian penulis yang berbicara tentang adanya informasi hoaks, yaitu informasi yang masih perlu dicek dan dibuktikan kebenarannya. Utamanya, informan dalam penelitian penuli menjelaskan bahwa informasi hoaks yang biasa tersebar dalam interaksi antar anggota keluarga tersebut adalah informasi tentang agama, biasanya bersifat kajian syiar dakwah, dan informasi tentang kesehatan. Informasi kesehatan ini biasanya tentang pengobatan herbal, pola hidup sehat, makanan yang menimbulkan berbagai penyakit, dan lain-lain.

Menurut IDR, informasi hoaks tersebut biasanya tersebar karena faktor ketidaktahuan anggota keluarganya. Jadi, langkah penyaringannya ada dalam diri anggota keluarga lainnya, ketika menerima informasi tersebut, sebaiknya dicek dahulu kebenarannya. Artinya, sebagai anggota keluarga harus aktif mencaritahu kebenaran informasi yang diterima.

\section{Temuan ketiga: wadah interaksi antar anggota keluarga yang berjauhan}

Penulis melihat temuan yang ketiga adalah adanya wadah silaturahmi yang menjadi tempat berinteraksi antar anggota keluarga, khususnya anggota keluarga yang berjauhan lokasi tempat tinggalnya. IDR menjelaskan dalam kutipan wawancaranya, sebagai berikut:

"Aksesibilitas media sosial ini sebetulnya menjadikan anggota keluarga jadi mudah berinteraksi ya, tempat silaturahmi juga, kan terwadahi dalam group misalnya. Kalau mau update informasi, sharing, berkomunikasi, ya memang dilakukan dalam group media sosial tersebut. “

KW juga menjelaskan hal yang sama dengan pernyataan IDR di atas, bahwa aksesibilitas media sosial ini menjadi sarana silaturahmi yang memudahkan interaksi antar anggota keluarga. Artinya, setiap anggota keluarga bisa saling berinteraksi melalui group media sosial tersebut. 
Arfaa \& Wang (2014) menjelaskan penelitiannya tentang kajian orang tua yang menjadi pengguna situs jejaring sosial. Meskipun jumlah orang tua telah meningkat dalam beberapa tahun terakhir, banyak yang tidak terlibat dengan media sosial. Adakah alasan khusus bagi lansia untuk tidak memanfaatkan media sosial? Adakah tantangan aksesibilitas dan kegunaan bagi lansia untuk menggunakan media sosial? Artikel tersebut melaporkan temuan awal untuk pertanyaan di atas berdasarkan catatan instruktur pada diskusi bersama orang tua dengan evaluasi aksesibilitas situs media sosial populer. Hasil penelitian menunjukkan bahwa kalangan orang tua berjuang menafsirkan cara penggunaan jejaring media sosial. Temuan dari penelitian tersebut berkontribusi pada pemahaman orang tua sebagai kelompok pengguna dan meningkatkan desain situs web yang lebih mudah diakses untuk orang tua (Arfaa, J., \& Wang, 2014).

Jika melihat hasil penelitian Arfaa \& Wang (2014) di atas, penulis melihat bahwa aksesibilitas media sosial bagi kalangan orang tua masih terbatas, sehingga rekomendasi penelitiannya pun menunjukkan adanya kemudahan desain situs web agar mudah diakses oleh kalangan orang tua. Hal ini berhubungan dengan temuan ketiga dalam penelitian penulis, bahwa media sosial memang diharapkan dapat diakses oleh semua kalangan, termasuk kalangan orang tua. Hal ini terlihat jelas dalam penelitian penulis bahwa aksesibilitas media sosial pun digunakan dalam interaksi antar anggota keluarga urban. Point lainnya adalah aksesibilitas media sosial ini menjadi wadah interaksi antar anggota keluarga yang lokasi tempat tinggalnya berjauhan, misalnya antar pulau atau bahkan antar negara.

Berdasarkan penelitian ini, penulis juga menemukan bahwa jenis media sosial yang diakses dan digunakan oleh para informan dalam interaksi antar anggota keluarganya ini adalah media sosial Whatsapp Group.

\section{PENUTUP}

Aksesibilitas media sosial dalam interaksi antar anggota keluarga urban ini menghasilkan temuan yang bervariatif, meliputi adanya konflik keluarga yang disebabkan oleh aksesibilitas media sosial tersebut; memungkinkan terjadinya penyebaran informasi hoaks dalam media sosial sebagai hasil dari interaksi anggota keluarga urban; munculnya jaringan group media sosial sebagai wadah interaksi antar anggota keluarga urban tersebut. Berdasarkan temuan tersebut, penulis melihat adanya point positif dan negatif yang dapat ditimbulkan sebagai hasil dari aksesibilitas media sosial yang digunakan dalam interaksi antar anggota keluarga urban.

\section{DAFTAR PUSTAKA}

Arfaa, J., \& Wang, Y. K. e). (2014). An accessibility evaluation of social media websites for elder adults. In International Conference on Social Computing and Social Media. Springer, Cham., 13-24.

Bungin, B. (2007). Analisis Data Penelitian Kualitatif(eds) Divisi Buku Perguruan Tinggi. Jakarta : PT Raja Grafindo Persada.

Derwin, Derwin; Suharto, Suharto; \& SYamsuri, S. (2016). Aksesibilitas Media Sosial Dakwah Mahasiswa Komunikasi Penyiaran Islam (KPI) IAIN Palu. Al Mishbah, 12(2), 183-210.

Lee, S. J., \& Chae, Y. G. (2007). Children's Internet use in a family context: Influence on 
family relationships and parental mediation. CyberPsychology \& Behavior, 10(5), 640-644., 10(5), 640-644.

Odabasi, H. F. (2005). Parent's Views on Internet Use. Turkish Online Journal of Educational Technology-TOJET, 4(1), 38-45.

Pinheiro, A., Cappelli, C., \& Maciel, C. (2014). Increasing information auditability for social network users. In International Conference on Human Interface and the Management of Information. Springer, Cham., 536-547.

Wilding, R. (2006). 'Virtual'intimacies? Families communicating across transnational contexts. Global networks, 6(2), 125-142. Global Networks, 6(2), 125-142. 